研究

\title{
放電プラズマ焼結法によるプロトン伝導性 $\mathrm{Sr}$ 添加 $\mathrm{LaPO}_{4}$ 焼結体の作製
}

\author{
雨澤 浩史社, 西川 義人や 2 , 冨井 洋一个 3 , 山本 值一个 4 \\ 出1 京都大学大学院人間・環境学研究科, $\overline{0}$ 606-8501 京都市左京区吉田二本松町. \\ 中2 大阪府立産業技術総合研究所，广594-1157 大阪府和泉市あゆみ野 2-7-1. \\ 出3 京都大学大学院エネルギー科学研究科, $=$ 606-8501 京都市左京区吉田本町. \\ 的 4 京都大学大学院理学研究科, $\bar{T}$ 606-8502 京都市左京区北白川追分町.
}

\section{Preparation of Proton Conducting Sr-Doped $\mathrm{LaPO}_{4}$ Ceramics with the Spark Plasma Sintering Method}

\author{
Koji Amezawa ${ }^{\text {मे }}$, Yoshito Nishikawa ${ }^{\text {मे } 2}$, Yoichi Tomii ${ }^{\text {मै }}$ and Naoichi Yamamoto ${ }^{\text {म4 }}$ \\ ${ }^{4}{ }^{1}$ Graduate School of Human and Environmental Studies, Kyoto University, Sakyo-ku, Kyoto 606-8501. \\ ${ }^{2}$ Technology Research Institute of Osaka Prefecture, 2-7-1 Ayumino, Izumi 594-1157. \\ ${ }^{3}{ }^{3}$ Graduate School of Energy Science, Kyoto University, Sakyo-ku, Kyoto 606-8501. \\ ${ }^{4}{ }^{4}$ Graduate School of Science, Kyoto University, Sakyo-ku, Kyoto 606-8502,
}

Received August 11, 2003

\section{SYNOPSIS}

The spark plasma sintering (SPS) method was employed to prepare sintered specimens of proton conducting Sr-doped $\mathrm{LaPO}_{4}$ ceramics. The relative densities of the sintered Sr-doped $\mathrm{LaPO}_{4}$ were around $99 \%$ when higher sintering temperatures than $1050^{\circ} \mathrm{C}$ were applied for the SPS process, while only $93 \%$ of relative density was achieved with the conventional pressure-less sintering (PLS) method at $1200^{\circ} \mathrm{C}$. Electrical conduction properties of the sintered samples with the SPS method at $1200^{\circ} \mathrm{C}$ were evaluated by using conductivity measurements at $500 \sim 930^{\circ} \mathrm{C}$ under $0.4 \sim 5 \mathrm{kPa}$ of $p\left(\mathrm{H}_{2} \mathrm{O}\right)$ or $p\left(D_{2} \mathrm{O}\right)$ and $0.01 \sim 100 \mathrm{kPa}$ of $p\left(\mathrm{O}_{2}\right)$. The specimen prepared with the SPS method showed similar conductivities and conduction properties as that prepared with the PLS method. These results suggested that the SPS method was a useful sintering technique to prepare proton conducting phosphate-based ceramics with a high density while keeping a feature of protonic conduction.

\section{KEY WORDS}

Spark plasma sintering, lanthanum phosphate, protonic conduction

\section{1 緒 言}

$500 \sim 1000^{\circ} \mathrm{C}$ の比較的高い温度域においてプロトン伝導性 を示すいわゆる高温型プロトン伝導体は, 燃料電池や水素(水 蒸気)センサー, 水素ポンプなど電気化学水素デバイス用電解 質材料としての応用が期待されている材料である ${ }^{1-3)}$. 高温型 プロトン质導体としては, 今までのところぺロブスカイト型 の結晶構造をもつ酸化物系材料が最も良く知られており， $\mathrm{BaCeO}_{3}, \mathrm{SrCeO}_{3}, \mathrm{CaZrO}_{3}$ といった材料を中心に広く研究が進め られてきた ${ }^{1-3)}$.これらの材料は，本来，結晶中にプロトンを 含んでいないにも関わらず，アクセプターカチオンの添加に よって生じる酸素空孔と雾囲気中の水蒸気等水素源ガスとの 平衡によって導入される格子間プロトンによってプロトン层 導性を発現する。これらの材料のうち, 現在, $\mathrm{CaZr}_{1-\mathrm{x}} \mathrm{In}_{\mathrm{x}} \mathrm{O}_{3-\delta}$ がアルミニウム鋳造工程における残留水素のモニタリング用 センサーの電解質材料として実用化されている. しかしなが
ら燃料電池など他の応用に対しては, プロトン伝導率, 化学 的安定性の点で問題を有しており，その改善が検討課題とさ れている.

一方, 高温プロトン伝導性は上記のペロブスカイト型酸化 物以外の材料においても見出されており ${ }^{1-4 ， そ の よ う な 中 て ゙ ~}$ 篚者等はりン酸塩を始めとするオキソ酸塩を母体とした材料 に着目して研究を行ってきた. その結果これまでに，オルト リン酸塩 $\mathrm{LnPO}_{4}(\mathrm{Ln}=\mathrm{La}, \mathrm{Pr}, \mathrm{Nd}, \mathrm{Sm}, \mathrm{Y})$ ，オキシリン酸塩 $\mathrm{La}_{7} \mathrm{P}_{3} \mathrm{O}_{18}$ ，ポリリン酸塩 $\mathrm{LaP}_{3} \mathrm{O}_{9}$, オルトホウ酸塩 $\mathrm{LnBO}_{3}(\mathrm{Ln}=$ La, Nd)など一連の希土類オキソ酸塩において, 希土類イオン の一部をSr, Caなどの2価カチオンで置換し，かつ湿润霉囲気 で用いることにより，高温プロトン伝導性が発現することを 報告した ${ }^{5-16}$. これらオキソ酸塩系高温型プロトン伝導体は， 導電率では従来の酸化物系材料に劣るものの, 酸化物系材料 で問題となっていた電子(ホール)や酸化物イオンによる伝導 
がプロトン伝導に比べて非常に小さく, かつ䨌囲気によらず 化学的に安定であることから注目されている.

希土類オキソ酸塩系材料におけるプロトン伝導の発現につ いては，2 価カチオン $\mathrm{M}$ を添加した希土類オルトリン酸塩 $\mathrm{LnPO}_{4}$ を用いた筆者等の研究により, 以下のような欠陥構造 モデルに基づく機構が提案されている ${ }^{5,6,10)}$.

$$
\begin{aligned}
& \frac{1}{2} \mathrm{M}_{2} \mathrm{P}_{2} \mathrm{O}_{7} \rightarrow \mathrm{M}_{\mathrm{Ln}}^{\prime}+\frac{1}{2}\left(\mathrm{P}_{2} \mathrm{O}_{7}\right)_{2 \mathrm{PO}_{4}}^{\ddot{*}} \\
& \frac{1}{2}\left(\mathrm{P}_{2} \mathrm{O}_{7}\right)_{2 \mathrm{PO}_{4}}^{* \cdot}+\frac{1}{2} \mathrm{H}_{2} \mathrm{O}(\mathrm{g}) \leftrightarrow\left(\mathrm{HPO}_{4}\right)_{\mathrm{PO}_{4}}^{\cdot}
\end{aligned}
$$

ここで各欠陥の記述は Kröger-Vink の表記法に従っている. (1)式は2価カチオンが希土類サイトに置換固溶することによ り, 酸素欠損としてピロリン酸基が生成されることを表して いる. 一方 (2)式は，(1)式に従って生成された酸素欠損とし てのピロリン酸基と雾囲気中の水蒸気との平衡により, プロ トンがリン酸水素基の形で結晶中に導入されることを表して いる. 希土類オルトリン酸塩における高温プロトン伝導性は, このようにして導入されたプロトンが結晶中でリン酸水素基 を形成しながら移動することにより発現すると考えられる.

一般に高温型プロトン伝導体を燃料電池を始めとする電気 化学水素デバイスに利用しようとする場合, 緻密でガスタイ 卜な焼結体試料が必要とされる. しかしながら上述のオキソ 酸塩系高温型プロトン伝導体では焼結温度を高くすると, 添 加した2価力チオンが不純物相として析出したりの, あるいは

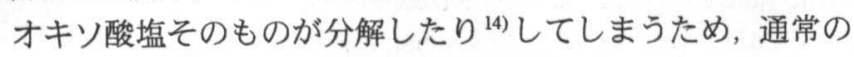
焼結体作製に用いられる常圧焼結法 (Pressure-less sintering method, 以下 PLS 法 ) では緻密な焼結体を得ることが困難で あった. そこで本研究では, オキソ酸塩系高温型プロトン伝 導体として Srを添加した $\mathrm{LaPO}_{4}$ を例にとり, 放電プラズマ焼 結法 (Spark plasma sintering method，以下 SPS 法)を用いた同 材料の低温焼結ならびに緻密化の可能性について検討した. また SPS 法における種々の焼結条件が試料の緻密性, 組織形 態に及ぼす影響についても検討した. 一般にSPS 法による焼 結過程では, 非常に強い還元性雾囲気のもと試料に通電がな される. そのため, イオンが電荷担体であるイオン伝導性固 体の焼結体作製にSPS 法を用いる場合, その特殊な焼結条件 が試料の安定性や組成の均一性, ひいては電気伝導特性に悪 影響を及ぼすといった問題が懸念されるものの, これらの点 については未だ明らかにされていない. 以上を踏まえ, 本研 究ではSPS 法によって作製された試料の電気伝導特性を, 種々の温度, 水蒸気分圧, 酸素分圧下における導電率測定を 通して明らかにすると共に, 従来のPLS 法によって作製され た試料の電気伝導特性と比較検討することにより, オキソ酸 塩系高温型プロトン伝導体の焼結に対するSPS 法の有効性に ついて確認した.

\section{2 実験方法}

実験に用いた $\mathrm{Sr}$ 添加 $\mathrm{LaPO}_{4}$ は, $\mathrm{LaPO}_{4}$ と $\mathrm{SrHPO}_{4}$ の固相反応
によって作製した. $\mathrm{LaPO}_{4}$ は, 等量の $0.2 \mathrm{~mol} / \ell \mathrm{La}\left(\mathrm{NO}_{3}\right)_{3}$ 水溶液 と $0.2 \mathrm{~mol} / \ell\left(\mathrm{NH}_{4}\right)_{2} \mathrm{HPO}_{4}$ 水溶液を擋汼混合し, その際に生成した 沈殿を遠心分離, 洗浄した後, $120^{\circ} \mathrm{C}$ で乾燥, $800^{\circ} \mathrm{C}$ で熱処理 することによって得た. また $\mathrm{SrHPO}_{4}$ は, 各 $0.2 \mathrm{~mol} / \ell$ $\mathrm{Sr}\left(\mathrm{NO}_{3}\right)_{2}$, $\mathrm{NH}_{4} \mathrm{H}_{2} \mathrm{PO}_{4}$ 硝酸酸性水溶液に $\mathrm{pH} 4$ を保つように $1 \mathrm{~mol} / \ell \mathrm{NH}_{3}$ 水 溶液を加えながら擋汼し, その際に生成した沈殿を吸引ろ過, 洗浄後, $120^{\circ} \mathrm{C}$ で乾燥熱処理して得た. このようにして得ら れた $\mathrm{LaPO}_{4}$ および $\mathrm{SrHPO}_{4}$ の各粉末を所定量秤量し, アルミナ 乳鉢で混合した後, $1000^{\circ} \mathrm{C}, 5$ 時間仮焼きしたものを原料粉 末とした. $1 \mathrm{~mol} \% \mathrm{Sr}$ 添加 $\mathrm{LaPO}_{4}$ の仮焼き後の原料は, Fig.1に SEM 写真を示した通り，100 500 nm 程度の粒サイズを持つ 粉末であった.

焼結体の作製は, 黒鉛製のダイ (内径 $\phi 30 \mathrm{~mm}$, 外径 $\phi 70 \mathrm{~mm}$, 高さ $70 \mathrm{~mm}$ ) およびパンチ ( 径 $\phi 30 \mathrm{~mm}$, 高さ $35 \mathrm{~mm}$ ) を用い, 放電プラズマ装置(住友石炭鉱業(侏)SPS-1020)を使用して行っ た. パンチと試料粉末間にはカーボンシートを挿入した. 既 報の通り, $\mathrm{Sr}$ 添加 $\mathrm{LaPO}_{4}$ は $1350^{\circ} \mathrm{C}$ 以上の温度において熱処理 を行うと, 添加した $\mathrm{Sr}$ が不純物相 $\mathrm{Sr}_{3} \mathrm{La}\left(\mathrm{PO}_{4}\right)_{3}$ として析出して しまい, 結果として導電率を劣化させてしまうの.これを考慮し 本研究では, 温度 $1000 \sim 1300^{\circ} \mathrm{C}$, 加圧力 $10 \sim 50 \mathrm{MPa}$, 保持 時間 5 分を焼結条件とした. なお焼結は真空 ( 20Pa) 中にお いて行った. 得られた焼結体試料は, 付着した黒鉛を研磨, 洗 浄で除去した後, 密度測定, X線回折 (日本電子製JDX-8030W) による相同定, SEM (日本電子製 JSM-890)による破断面組織 観察を行った. なお, 同様にして作製した原料粉末を $392 \mathrm{MPa}$ の冷間等方圧プレスにより加圧成形した後, $1000 \sim 1500^{\circ} \mathrm{C} に$ おいて 5 時間焼成を行った常圧焼結法による焼結体を比較試 料とした.

導電率の測定には, SPS 法により焼結温度 $1200^{\circ} \mathrm{C}$, 加圧力 $50 \mathrm{MPa}$ ，保持時間 5 分の条件で作製された焼結体を, $3 \times 3 \times 28$ $\mathrm{mm}$ に切削加工した角柱状試料を用いた. なお測定は温度 500 $\sim 930^{\circ} \mathrm{C}$, 水蒸気 $\left(\mathrm{H}_{2} \mathrm{O}\right.$ あるいは $\left.\mathrm{D}_{2} \mathrm{O}\right)$ 分圧 $0.4 \sim 5 \mathrm{kPa}$, 酸素分 圧 $0.01 \sim 100 \mathrm{kPa}$ の条件下で行った. 測定の詳細については既 報と同様である 68,10$)$.

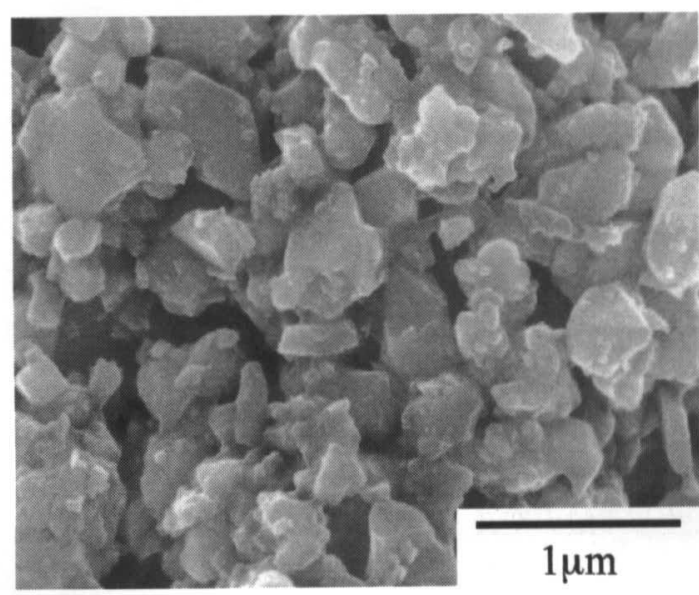

Fig.1 SEM image of $1 \mathrm{~mol} \% \mathrm{Sr}$-doped $\mathrm{LaPO}_{4}$ powder after calcination at $1000^{\circ} \mathrm{C}$. 


\section{3 実験結果および考察}

\section{$3.1 \mathrm{SPS}$ 法による $\mathrm{Sr}$ 添加 $\mathrm{LaPO}_{4}$ 焼結体の作製}

Fig. 2 K，加圧力 $50 \mathrm{MPa}$ ，焼結温度 $1000 \sim 1300^{\circ} \mathrm{C}$ ，保持時 間5分の条件でSPS法によって作製された $1 \mathrm{~mol} \% \mathrm{Sr}_{\text {r 添加LaPO }}$ 焼結体を粉碎して得た粉末 X線回折パターンを示す，全ての 試料において，モナザイト型 $\mathrm{LaPO}_{4}$ に帰属されるピークのみ が観測された. SPS 法では，焼結過程中において強い還元性 雾囲気のもと試料に通電が行われるため, 試料の還元や分解 が生じる恐れがあるが，本研究で用いた $1 \mathrm{~mol} \% \mathrm{Sr}$ 添加 $\mathrm{LaPO}_{4}$ の場合は，SPS処理後も少なくともX線回折パターンの上で は大きな変化は見られないことがわかった。

$1 \mathrm{~mol} \% \mathrm{Sr}$ 添加 $\mathrm{LaPO}_{4}$ 焼結体の緻密化に及ぼす SPS 温度の効 果をFig.3に示す.このときのSPS加圧力は50MPaとした. Fig.3 には比較試料として従来用いてきたPLS法によって作製され た烓結体の相对密度も合わせて示した．PLS 法によって作製 された試料では，焼結温度を上げるにつれて相対密度も徐々 に向上する傾向が見られはしたものの, $1200^{\circ} \mathrm{C}$ 以上の温度に なると相対密度もそれほど大きく変化しなくなることがわ かった，またその際の相対密度の值も， $1200^{\circ} \mathrm{C}$ で $93.0 \%, 1300^{\circ} \mathrm{C}$ で93.6\%であった.さらに温度を上げ $1400^{\circ} \mathrm{C}$ 以上の焼結温度 を用いれば緻密性はわずかに向上するが，前節において既に 述べた通り，この温度域での焼結では添加したSrが不純物相 として析出してしまい，プロトン层導特性を低下させてしま うの. 以上のことから，PLS 法を用いて Sr 添加 $\mathrm{LaPO}_{4}$ の焟結 を行った場合，少なくとも今回使用した原料粉末からでは充 分に緻密な焼結体試料を得るのは困難であることがわかった. 一方SPS法を用いて $1 \mathrm{~mol} \% \mathrm{Sr}$ 添加LaPO ${ }_{4}$ の焼結を行った場合, 焼結温度 $1000^{\circ} \mathrm{C}$ では $93.4 \%$ と充分な相対密度は得られなかっ

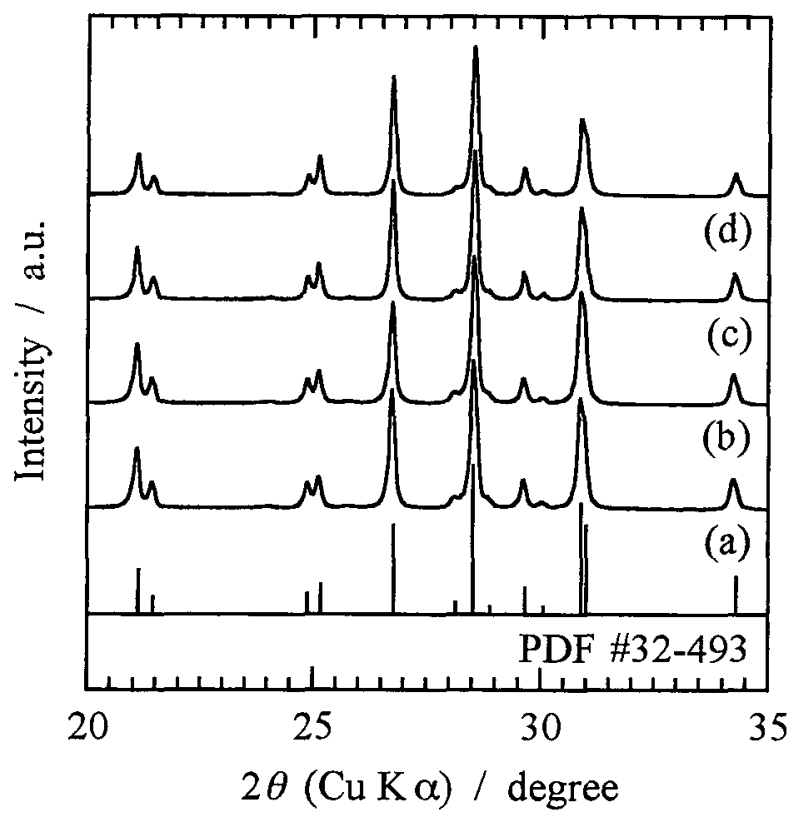

Fig.2 X-ray diffraction patterns of $1 \mathrm{~mol} \% \mathrm{Sr}$-doped $\mathrm{LaPO}_{4}$ prepared with the SPS method under $50 \mathrm{MPa}$ at (a) $1000^{\circ} \mathrm{C}$, (b) $1100^{\circ} \mathrm{C}$, (c) $1200^{\circ} \mathrm{C}$ and (d) $1300^{\circ} \mathrm{C}$.
たが，焼結温度が $1050^{\circ} \mathrm{C}$ 以上になると相対密度 98.6〜 98.9\% とほぼ理論密度に近い，非常に緻密な焼結体試料が得られる ことがわかった．以上の結果から，1 $1 \mathrm{~mol} \% \mathrm{Sr}$ 添加 $\mathrm{LaPO}_{4}$ の低 温焼結ならびに緻密化に対し，本研究で採用したSPS 法は非 常に有効な焼結手法であることが明らかとなった。

Fig.4 (a) (d) に, 加圧力 $50 \mathrm{MPa}$ ，焼結温度 $1000 \sim 1300{ }^{\circ} \mathrm{C}$, 保持時間 5 分の条件でSPS 法によって作製された $1 \mathrm{~mol} \% \mathrm{Sr}$ 添 加 $\mathrm{LaPO}_{4}$ 焼結体の破断面組織を示す。焼結温度が $1000^{\circ} \mathrm{C}$ の場 合，各粉末は充分に暁結しておらず，また空淂も多く観測さ れた。これに対し焼結温度が $1100^{\circ} \mathrm{C}$ 以上になると，空隙の少 ない非常に維密な焼結体が得られることがわかった.これら の結果は, Fig.3に示した密度測定の結果とよく一致してい る.また $1100^{\circ} \mathrm{C}$ において得られた焼結体は, $500 \mathrm{~nm} \sim 1 \mu \mathrm{m}$ 程 度の比較的均一な粒サイズ・組織形態をしており，Fig.1に示 した原料粉末のサイズと比較してもそれほど粒成長をしてい

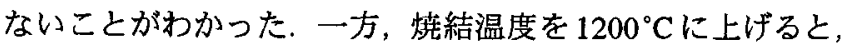
$1100^{\circ} \mathrm{C} て ゙ の$ 焼結体と同じような粒サイズ・形態をしている部 分もあるものの(Fig.4 (a), (b) と Fig.4 (c), (d) では撮影倍率が異 なることに注意されたい)，随所に異常粒成長した $10 \sim 20 \mu \mathrm{m}$

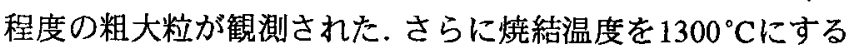
と，ほぼ全体が10 20 $\mu \mathrm{m}$ 程度の粗大粒からなる焼結体が得ら れることがわかった.以上の結果から，SPS法を用いた $1 \mathrm{~mol} \%$ $\mathrm{Sr}$ 添加 $\mathrm{LaPO}_{4}$ の焼結では，焼結温度に依存して焼結体におけ る組織形態が大きく変化することがわかった。

$1 \mathrm{~mol} \% \mathrm{Sr}$ 添加 $\mathrm{LaPO}_{4}$ 焼結体の緻密化に及ぼす SPS 加圧力の 効果をFig.5に示す. Fig.5には参考のため, PLS法によって作 製された試料の密度も加圧力のない場合の結果として示した. SPS 法によって作製された試料の密度は，焼結の際に加圧を 行わないPLS 法を用いた場合に比べると格段に向上した。し

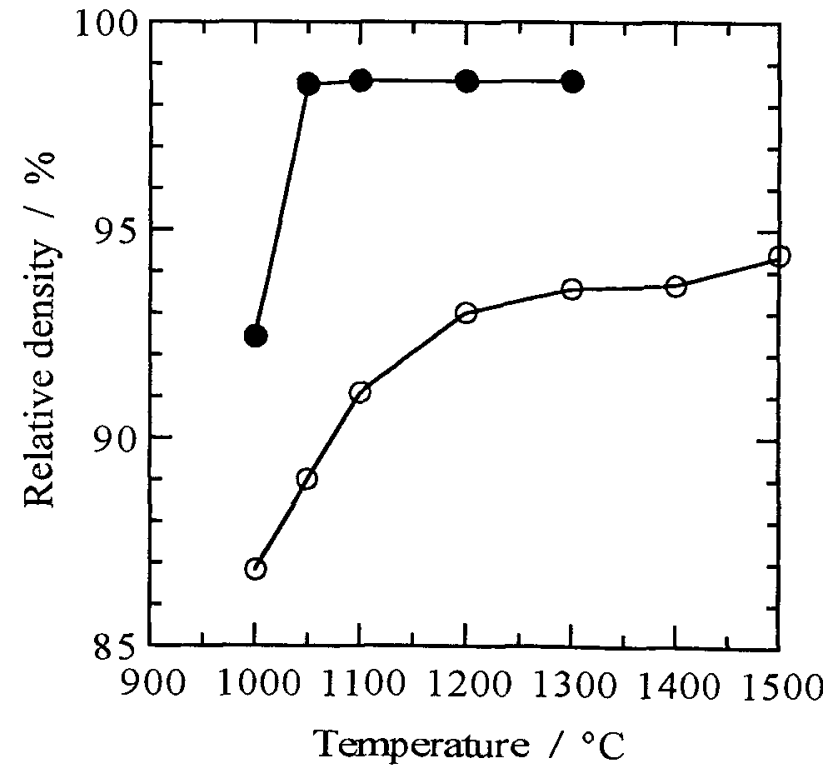

Fig.3 Relative density of 1 mol\% $\mathrm{Sr}$-doped $\mathrm{LaPO}_{4}$ prepared with the SPS (O) and the PLS (O) methods at various sintering temperatures. 
(a)
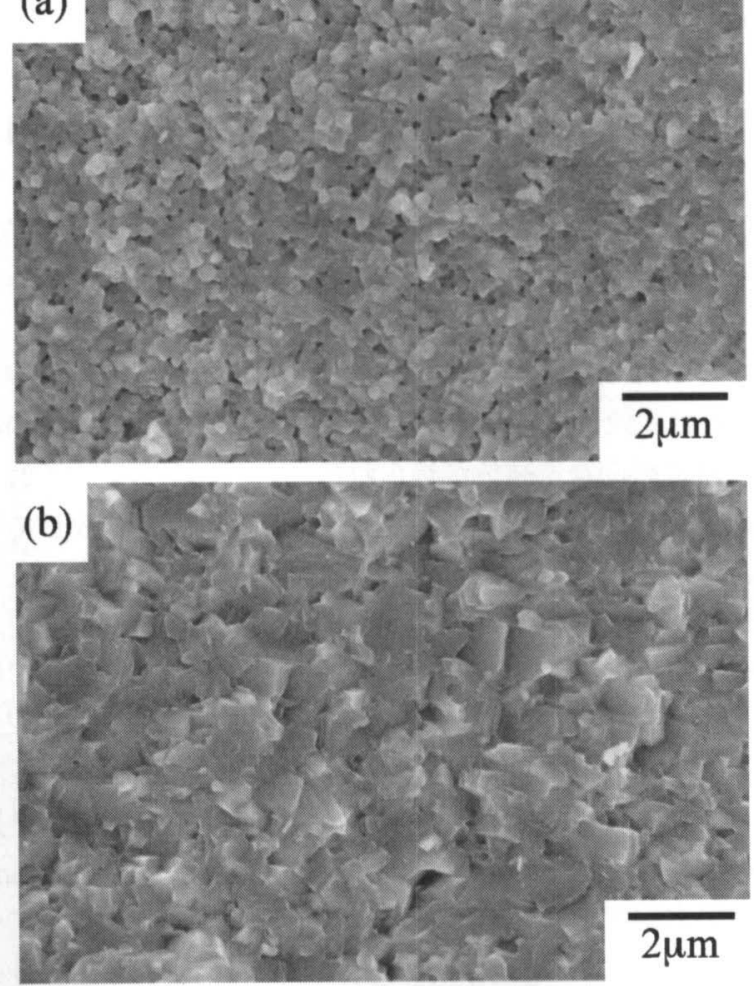

(c)
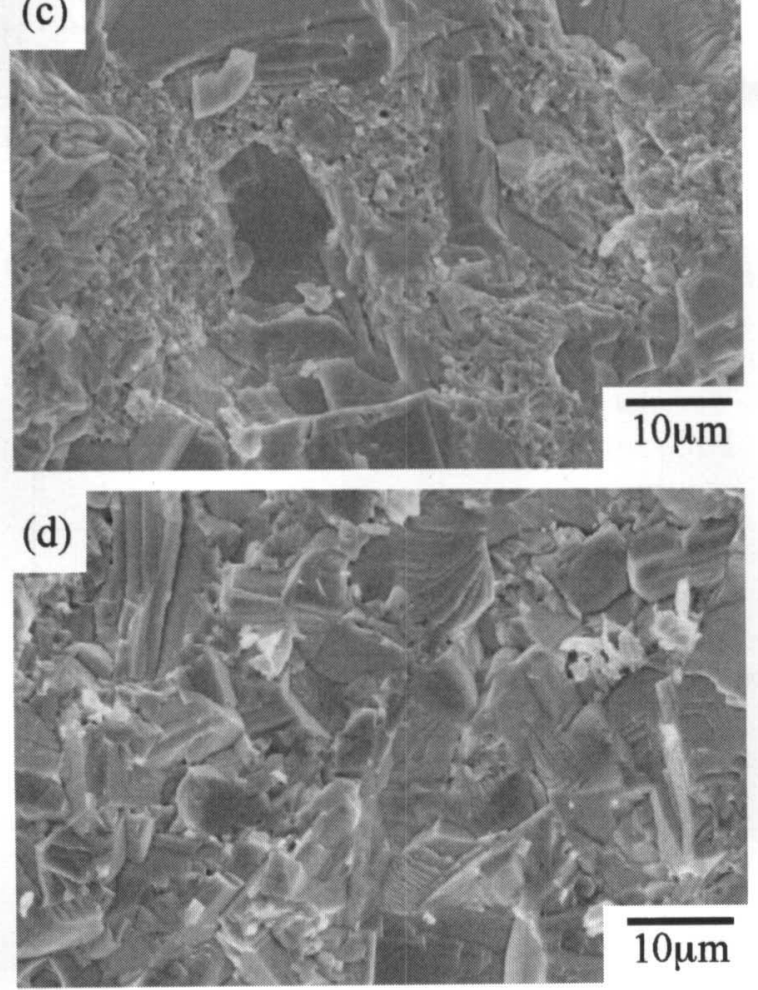

Fig.4 SEM images of fractured surface of $1 \mathrm{~mol} \% \mathrm{Sr}$-doped $\mathrm{LaPO}_{4}$ prepared with the SPS method under $50 \mathrm{MPa}$ at (a) $1000^{\circ} \mathrm{C}$, (b) $1100^{\circ} \mathrm{C}$, (c) $1200^{\circ} \mathrm{C}$ and (d) $1300^{\circ} \mathrm{C}$.

かしながら SPS 法を用いた場合, $1050,1200^{\circ} \mathrm{C}$ のどちらの焼 結温度においても, 焼結体密度は加圧力にはほとんど依存せ

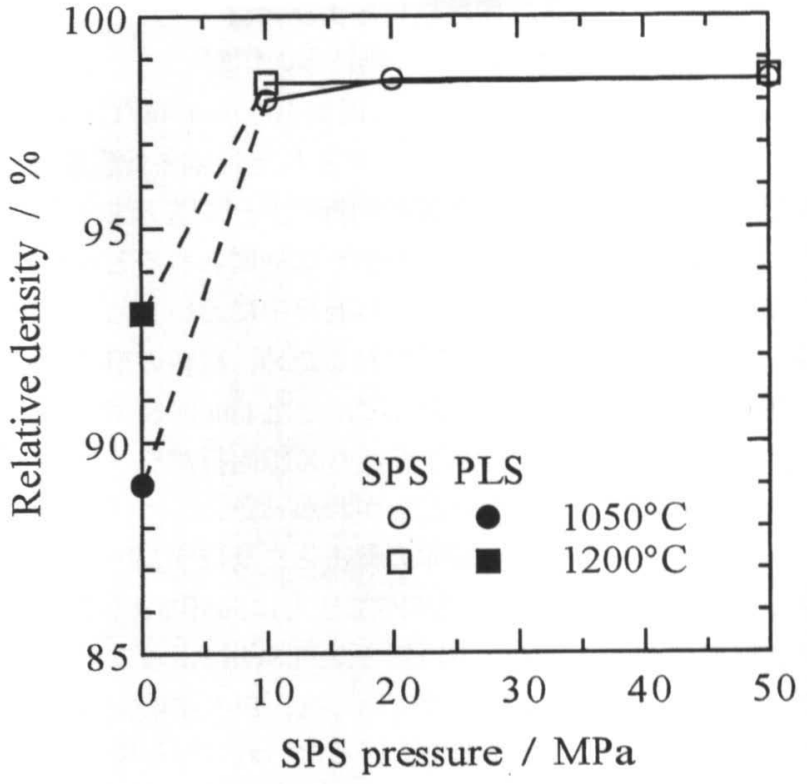

Fig.5 Relative density of $1 \mathrm{~mol} \% \mathrm{Sr}$-doped $\mathrm{LaPO}_{4}$ prepared with the SPS method at $1050^{\circ} \mathrm{C}(O)$ and $1200^{\circ} \mathrm{C}(\square)$ under various SPS pressures.

ず, 少なくとも10 50MPaの圧力範囲では加圧力によらず緻 密な焼結体が得られることがわかった.

Fig.6(b) (d) に, 焼結温度 $1050^{\circ} \mathrm{C}$, 加圧力 $10 \sim 50 \mathrm{MPa}$, 保 持時間 5 分の条件で SPS 法によって作製された $1 \mathrm{~mol} \% \mathrm{Sr}$ 添加 $\mathrm{LaPO}_{4}$ 焼結体の破断面組織を示す. Fig.6 (a)には, 従来のPLS 法を用いて同じ燒結温度において作製された焼結体の破断面 組織を示した. PLS 法によって作製された試料では, 充分に 焼結が行われておらず空隙も非常に多いのに対し，SPS 法に よって作製された試料では非常に緻密な焼結体が得られてい ることがわかった．また SPS 法による焼結体においては, い ずれの加圧力を用いた場合もよく似た組織形態をしており, $500 \mathrm{~nm} \sim 1 \mu \mathrm{m}$ 程度のほぼ均一なサイズの粒によって構成され ていることがわかった. 以上の結果から, SPS 法を用いた $1 \mathrm{~mol} \% \mathrm{Sr}$ 添加 $\mathrm{LaPO}_{4}$ の焼結では, 加圧力は密度や組織形態に それほど影響を及ほさないことが明らかとなった。

$3.2 \mathrm{SPS}$ 法による $\mathrm{Sr}$ 添加 $\mathrm{LaPO}_{4}$ 焼結体の電気伝導特性

“焼結温度 $1200^{\circ} \mathrm{C}$, 加圧力 $50 \mathrm{MPa}$, 保持時間 5 分の条件でSPS 法により作製された $1 \mathrm{~mol} \% \mathrm{Sr}$ 添加 $\mathrm{LaPO}_{4}$ 燒結体について, 湿 潤 $\left(p\left(\mathrm{H}_{2} \mathrm{O}\right)=4.2 \mathrm{kPa}\right)$ および乾燥雲囲気下において測定された 導電率を Fig.7に示す. $1 \mathrm{~mol} \% \mathrm{Sr}$ 添加 $\mathrm{LaPO}_{4}$ は乾燥雾囲気下よ りも湿潤䨌囲気下において約半〜一桁高い導電率を示した. このような湿度に対する導電率の挙動は, 外部雾囲気中の水 蒸気と試料との平衡によって伝導プロトンが導入される高温 型プロトン伝導体によく見られるものであり, SPS 法による $1 \mathrm{~mol} \% \mathrm{Sr}$ 添加 $\mathrm{LaPO}_{4}$ 焼結体におけるプロトン伝導性が示唆さ れた. Fig.7には, PLS法によって $1200^{\circ} \mathrm{C} て ゙$ 作製された $1 \mathrm{~mol} \%$ $\mathrm{Sr}$ 添加 $\mathrm{LaPO}_{4}$ 焼結体の導電率も合わせて示した ${ }^{8,10)}$. 実線が湿 潤, 破線が乾燥䨌囲気下における導電率を表している. Fig.7 

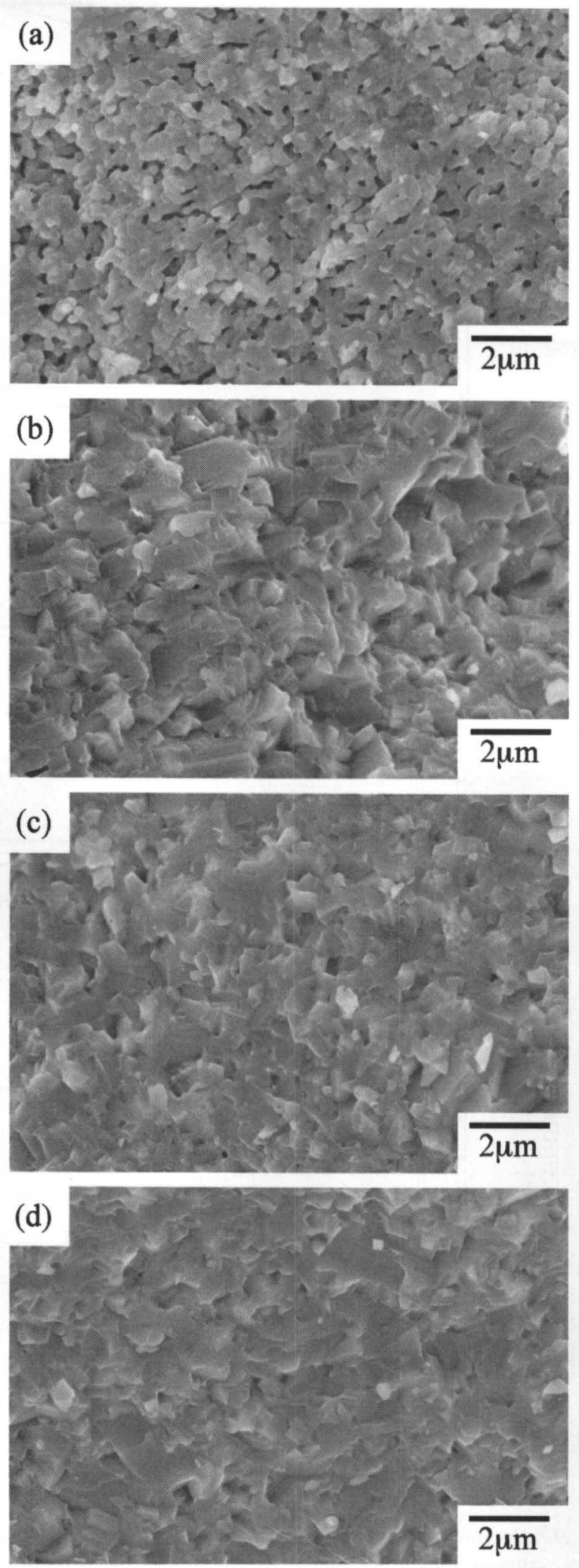

Fig.6 SEM images of fractured surface of $1 \mathrm{~mol} \% \mathrm{Sr}$-doped $\mathrm{LaPO}_{4}$ prepared with (a) the PLS method, and with the SPS method at $1050^{\circ} \mathrm{C}$ under (b) $10 \mathrm{MPa}$, (c) $20 \mathrm{MPa}$ and (d) $50 \mathrm{MPa}$.

からも明らかな通り, 本研究において SPS 法により作製され た焼結体は, 従来のPLS 法により作製された試料とほぼ同等

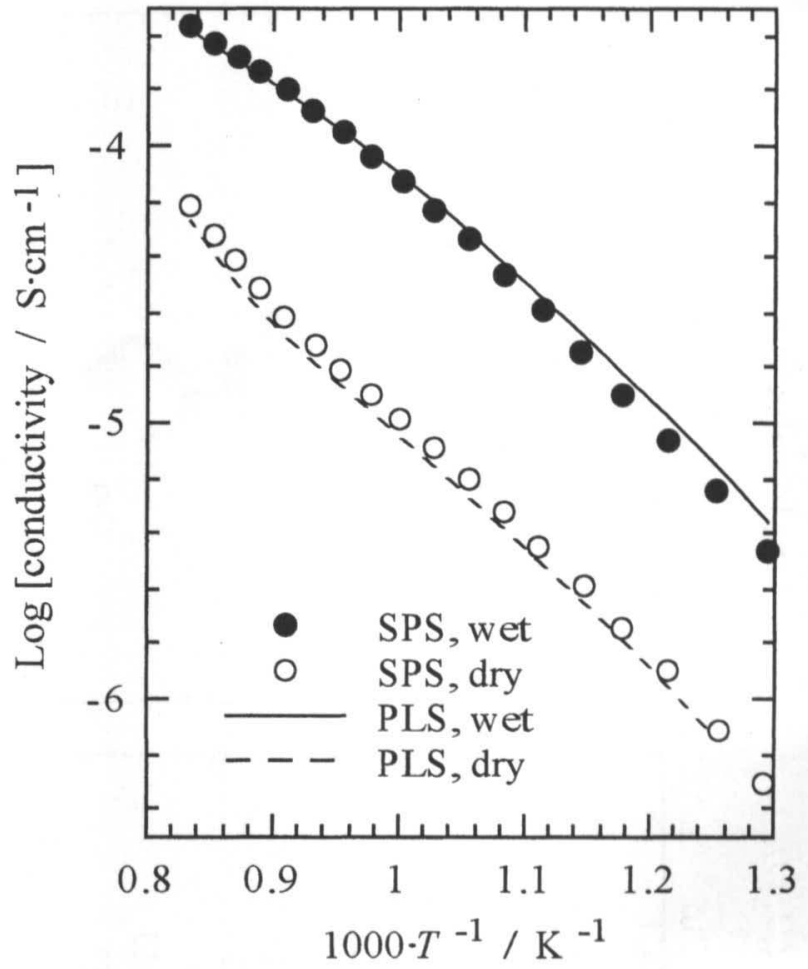

Fig.7 Conductivities of $1 \mathrm{~mol} \% \mathrm{Sr}$-doped $\mathrm{LaPO}_{4}$ prepared with the SPS method under $50 \mathrm{MPa}$ at $1200^{\circ} \mathrm{C}$. Conductivities were measured under wet $\left(p\left(\mathrm{H}_{2} \mathrm{O}\right)=4.2 \mathrm{kPa}\right)$ and dry conditions at $p\left(O_{2}\right)=1 \mathrm{kPa}$. The solid and dotted lines represent conductivities of $1 \mathrm{~mol} \% \mathrm{Sr}$-doped $\mathrm{LaPO}_{4}$ prepared with the PLS method at $1200^{\circ} \mathrm{C}$.

の導電率値を示し, また湿潤, 乾燥雾囲気下における導電率 の挙動も非常に似たものであることがわかった.

SPS 法により作製された試料におけるプロトン伝導性につ いて確認するために, 酸素分圧を一定に保ち, 重水による湿 潤霧囲気下において同様の導電率測定を行った. Fig.8 (a)にそ の結果を, また Fig. 8 (b) に軽水・重水湿潤雾囲気下における 導電率の比を示す. 測定を行った全ての温度において, 重水 よりも軽水による湿潤䨌囲気下においてより高い導電率が観 測された.このように, SPS 法により作製された $1 \mathrm{~mol} \% \mathrm{Sr}$ 添 加 $\mathrm{LaPO}_{4}$ 焼結体においても導電率の同位体効果が明膫に観測 されたことから, 同焼結体がプロトン伝導性を示すこと, ま た质導するプロトンが需囲気中の水蒸気と試料との平衡に よって導入されることが確認された. さらにFig.8(b)より, 軽 水および重水雾囲気下における導電率の比はおよそ $1.2 \sim 1.3$ であることがわかる.これは単純なプロトンによるホッピン グ伝導を仮定した場合の古典的な運動論から予測される $\mathrm{H}$ と D の重量比に基づく理論値 $\sqrt{2}$ に近い值である. この結果か ら, SPS 法により作製された $1 \mathrm{~mol} \% \mathrm{Sr}$ 添加 $\mathrm{LaPO}_{4}$ 焼結体にお けるプロトン伝導が，PLS 法により作製された燒結体の場合 と同様, 非常に支配的であることが明らかとなった.

$\mathrm{SPS}$ 法による $1 \mathrm{~mol} \% \mathrm{Sr}$ 添加 $\mathrm{LaPO}_{4}$ 焼結体の導電率を種々の 水蒸気分圧において測定した結果を Fig.9(a)に示す. 測定を 

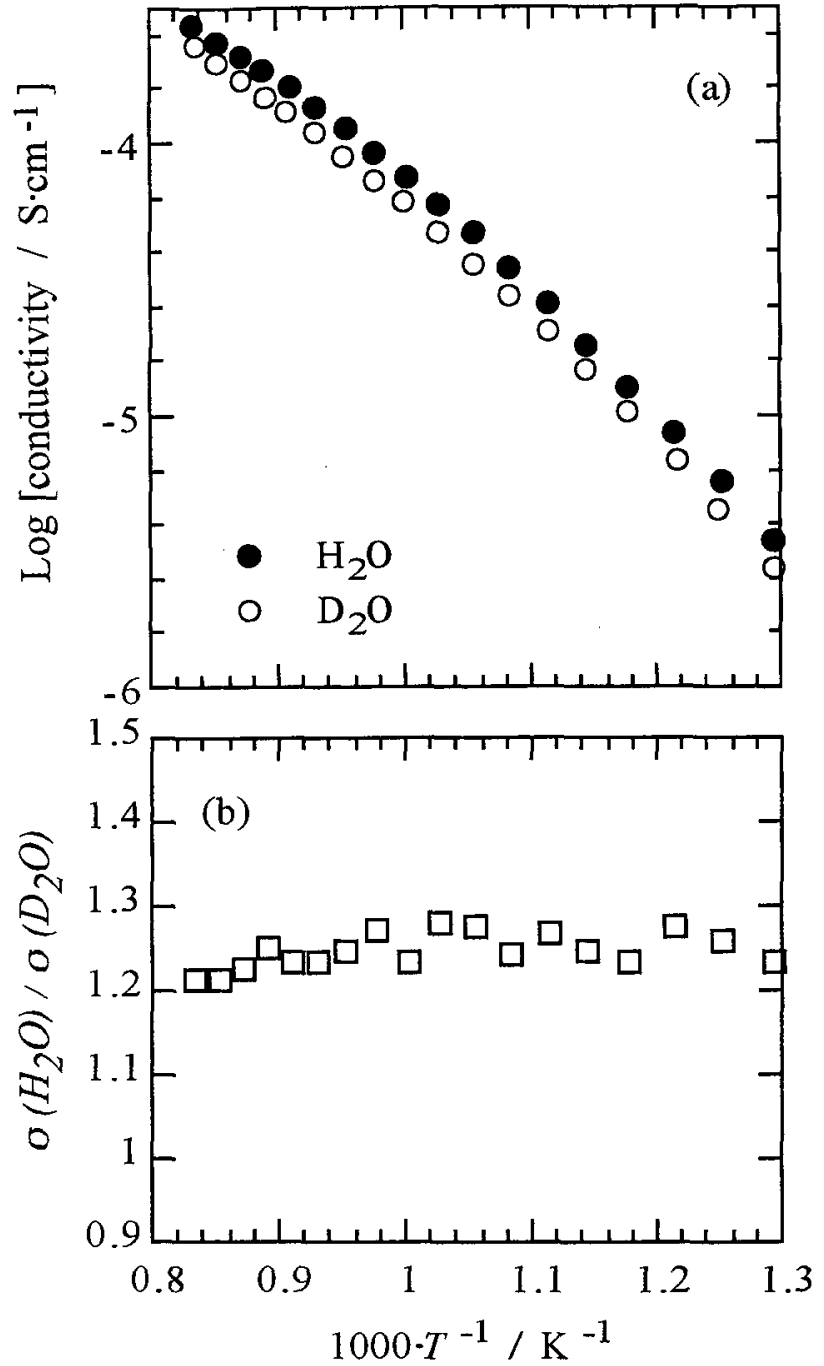

Fig.8 Isotope effect on conductivity of $1 \mathrm{~mol} \% \mathrm{Sr}$-doped $\mathrm{LaPO}_{4}$ prepared with the SPS method under $50 \mathrm{MPa}$ at $1200^{\circ} \mathrm{C}$. Conductivities were measured under $p\left(\mathrm{H}_{2} \mathrm{O}\right)$ or $p\left(\mathrm{D}_{2} \mathrm{O}\right)=$ $4.2 \mathrm{kPa}$ and $p\left(\mathrm{O}_{2}\right)=1 \mathrm{kPa}$.

行った全ての温度において, 水蒸気分圧が増加するに伴って 導電率も増加する傾向が見られた.これは(2)式の欠陥平衡で 表されるように, 外部雾团気中の水蒸気と試料との平衡に よって伝導プロトンが導入されることに対応していると考え られる. 同じ $1 \mathrm{~mol} \% \mathrm{Sr}$ 添加 $\mathrm{LaPO}_{4}$ 焼結体の導電率を酸素分圧 に対して測定した結果を Fig.9 (b) に示す. $500 \sim 700^{\circ} \mathrm{C}$ では, 導電率は酸素分圧にほとんど依存せず一定の值を示した。一 方 800 および $900^{\circ} \mathrm{C} て ゙ は ，$ 導電率はわずかではあるが酸素分 圧に依存し，酸素分圧の増加と共に導電率も増加する傾向が 見られた，このような導電率の酸素分圧依存性は，SPS 法に よる $\mathrm{Sr}$ 添加 $\mathrm{LaPO}_{4}$ 焼結体が，比較的低い温度ではほぼ純粋な プロトン伝導性を示すものの, 高温になるにつれてプロトン 伝導に加えホール伝導による奇与が現れることを示唆してい る. $\mathrm{Sr}$ 添加 $\mathrm{LaPO}_{4}$ におけるこのような $\mathrm{p}$ 型電子伝導は次のよ
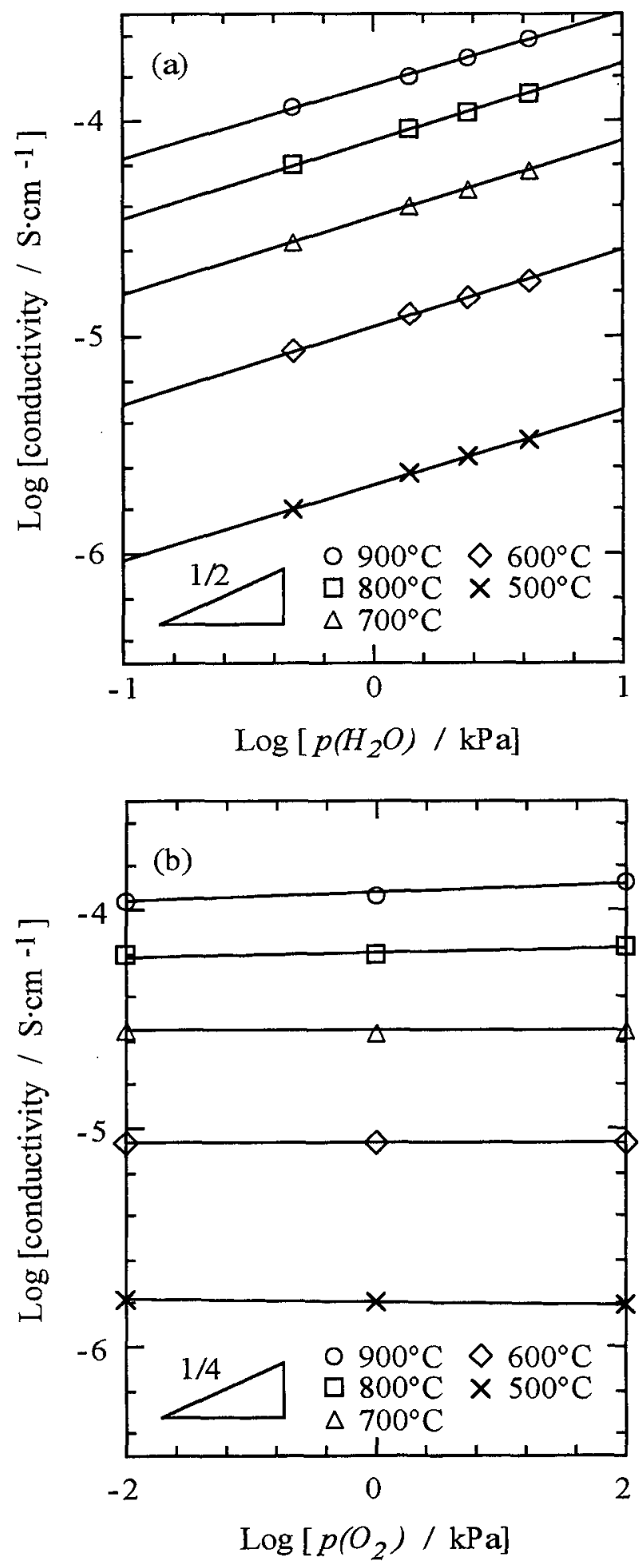

Fig.9 Conductivities of $1 \mathrm{~mol} \% \mathrm{Sr}$-doped $\mathrm{LaPO}_{4}$, prepared with the SPS method under $50 \mathrm{MPa}$ at $1200^{\circ} \mathrm{C}$, as a function of (a) $p\left(\mathrm{H}_{2} \mathrm{O}\right)$ at $p\left(\mathrm{O}_{2}\right)=1 \mathrm{kPa}$, and (b) $p\left(\mathrm{O}_{2}\right)$ at $p\left(\mathrm{H}_{2} \mathrm{O}\right)=0.48$ $\mathrm{kPa}$.

うな欠宿平衡により発現するものと考えられる6,10).

$$
\frac{1}{2}\left(\mathrm{P}_{2} \mathrm{O}_{7}\right)_{2 \mathrm{PO}_{4}}^{\cdot *}+\frac{1}{4} \mathrm{O}_{2}(\mathrm{~g}) \leftrightarrow\left(\mathrm{PO}_{4}\right)_{\mathrm{PO}_{4}}^{\mathrm{x}}+\mathrm{h}^{\bullet}
$$


一般にイオン伝導が支配的な材料においては，ホールのよ うな電子欠陮の濃度は非常に小さいと考えられる．従って $\mathrm{Sr}$ 添加 $\mathrm{LaPO}_{4}$ では電気的中性条件として

$$
2\left[\left(\mathrm{P}_{2} \mathrm{O}_{7}\right)_{2 \mathrm{PO}_{4}}^{*}\right]+\left[\left(\mathrm{HPO}_{4}\right)_{\mathrm{PO}_{4}}^{\cdot}\right]=\left[\mathrm{M}_{\mathrm{Ln}}\right]=\text { const. }
$$

が成り立つと仮定できる. (2)および(3)式で表される久陥平衡 の平衡定数をそれぞれ $K_{2}$ および $K_{3}$ とすると，(2) (4)式より， $\left(\mathrm{P}_{2} \mathrm{O}_{7}\right)_{2 \mathrm{PO} 4}^{*}$ が支配的な欠陥，すなわち $\left[\left(\mathrm{P}_{2} \mathrm{O}_{7}\right)_{2 \mathrm{PO} 4}^{*}\right] \gg\left[\left(\mathrm{HPO}_{4}\right)_{\mathrm{PO}_{4}}^{*}\right]$ である場合，各欠陌濃度は以下のように表すことができる。

$$
\begin{aligned}
& {\left[\left(\mathrm{HPO}_{4}\right)_{\mathrm{PO}_{4}}^{\cdot}\right]=K_{2}\left[\left[M_{L n}^{\prime}\right] / 2\right\}^{1 / 2}\left\{p\left(H_{2} \mathrm{O}\right)\right\}^{1 / 2}} \\
& {\left[\left(\mathrm{P}_{2} \mathrm{O}_{7}\right)_{2 \mathrm{PO}_{4}}^{*}\right]=\left[\mathrm{M}_{\mathrm{Ln}}\right] / 2} \\
& {\left[\mathrm{~h}^{\cdot}\right]=K_{3}\left[\left[M_{L_{n}}\right] / 2\right\}^{1 / 2}\left\{p\left(O_{2}\right)\right\}^{1 / 4}}
\end{aligned}
$$

同様にして, $\left(\mathrm{HPO}_{4}\right)_{\mathrm{PO} 4}^{\bullet}$ が支配的な欠陥，すなわち $\left[\left(\mathrm{P}_{2} \mathrm{O}_{7}\right)_{2 \mathrm{PO}_{4}}^{* *}\right]$ 《 $\left[\left(\mathrm{HPO}_{4}\right)_{\mathrm{PO} 4}^{\cdot}\right]$ である場合, 各欠陷濃度は以下のように表すこ とができる。

$$
\begin{aligned}
& {\left[\left(\mathrm{HPO}_{4}\right)_{\mathrm{PO}_{4}}^{-}\right]=\left[\mathrm{M}_{\mathrm{Ln}}\right]} \\
& {\left[\left(\mathrm{P}_{2} \mathrm{O}_{7}\right)_{2 \mathrm{PO}_{4}}^{-}\right]=\left[\mathrm{M}_{\mathrm{Ln}}^{\prime}\right]^{2} K_{2}^{-2}\left\{p\left(H_{2} O\right)\right\}^{-1}} \\
& {\left[\mathrm{~h}^{\circ}\right]=\left[\mathrm{M}_{\mathrm{Ln}}^{\prime}\right] K_{2}^{-1} K_{3}\left\{p\left(H_{2} O\right)\right\}^{-1 / 2}\left\{p\left(O_{2}\right)\right\}^{1 / 4}}
\end{aligned}
$$

Fig.8に見られる通り, SPS法による $1 \mathrm{~mol} \% \mathrm{Sr}$ 添加LaPO 4 焼結 体の導電率が明膫な同位体効果を示したことから，この焼結 体が支配的なプロトン伝導性を示すと考えられる. 従って, Fig.9 (a) および(b)に示される導電率の分圧依存性は，基本的 には試料中のプロトン濃度の分圧依存性に対応していると考 えられる. Fig.9(a)より, SPS法による $1 \mathrm{~mol} \% \mathrm{Sr}$ 添加 LaPO 4 焼 結体の導電率は，水蒸気分圧の対数に対し直線的に增加した. これらの直線の勾配は，いずれの温度においても，(5)式より 予測される $1 / 2$ 勾配に比較的近い值を示した.これらの結果 は，SPS 法による $1 \mathrm{~mol} \% \mathrm{Sr}$ 添加 $\mathrm{LaPO}_{4}$ 焼結体における支配 的な欠宿が酸素欠損 $\left(\mathrm{P}_{2} \mathrm{O}_{7}\right)_{2 \mathrm{PO} 4}^{-}$であり，支配的な導電種が $\left(\mathrm{HPO}_{4}\right)_{\mathrm{PO}}^{*}$ すなわちプロトンであることを示していると考えら れる.一方 Fig.9(b)に示した通り，SPS法による $\mathrm{Sr}$ 添加 $\mathrm{LaPO}_{4}$

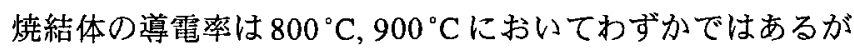
酸素分圧の増加と共に増加した. これは高温になるにつれて (7)式で表されるp型電子伝導による奇与が無視できなくなる ためと考えられる。しかしながら，その酸素分圧依存性は， (7)式から予測される酸素分圧の $1 / 4$ 乗則よりもかなり小さい 勾配であった. この結果は, SPS法による $1 \mathrm{~mol} \% \mathrm{Sr}$ 添加 $\mathrm{LaPO}_{4}$ 焼結体では, (5)式で表されるように酸素分圧に依存しないプ ロトン伝導が支配的であり, $\mathrm{p}$ 型電子伝導が全電気伝導に及ぼ

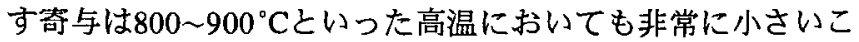
とを示唆している.

SPS 法により作製された $1 \mathrm{~mol} \% \mathrm{Sr}$ 添加 $\mathrm{LaPO}_{4}$ 焼結体試料に おいて得られた以上のような導電率の水蒸気分圧および酸素 分圧依存性の結果は，従来のPLS 法により作製された試料と 類似していた.このことから， $\mathrm{Sr}$ 添加 $\mathrm{LaPO}_{4}$ 焼結体の電気伝 導特性はSPS 法による焼結プロセスによっても変化しない， 言い換えれば，SPS 法を用いることにより $\mathrm{Sr}$ 添加 $\mathrm{LaPO}_{4}$ 烵結 体の電気伝導特性を保持したまま焼結体の密度を向上させ得 ることがわかった。

なお3.1節において述べた通り， SPS法を用いて $1 \mathrm{~mol} \% \mathrm{Sr}$ 添 加 $\mathrm{LaPO}_{4}$ の焼結を行った場合，焼結温度を変えることによっ て，蟒結体の組織形態を変化させられることがわかった.こ のような烓結体の組織形態の違いは，焼結体の電気的あるい は機械的特性に大きく影響を及ぼす可能性がある．この点に ついては現在検討中であり，詳細は追って報告する予定であ る.

\section{4 結 論}

本研究により以下の知見が得られた.

(1) プロトン伝導性 $\mathrm{Sr}$ 添加 $\mathrm{LaPO}_{4}$ の焼結に放電プラズマ焼結 法を用いることにより， $1050^{\circ} \mathrm{C}$ 以上の焼結温度において ほほ理論密度に近い非常に緻密な焼結体を得られることが わかった。

(2) 放電プラズマ焼結法によって作製された $\mathrm{Sr}$ 添加 $\mathrm{LaPO}_{4}$ 焼 結体では，焼結温度の上昇に伴い著しい粒成長が見られ た. 平均粒子サイズは, $1050^{\circ} \mathrm{C}$ 焼結の試料の場合 $500 \mathrm{~nm}$ 〜 $1 \mu \mathrm{m}$ 程度であったのに対し $1300^{\circ} \mathrm{C}$ 焼結の試料の場合 10 $\sim 20 \mu \mathrm{m}$ 程度まで変化した. 一方, 焼結体の密度・組織形 態は，10〜 50MPa の圧力範囲内では SPS 加圧力にはほと んど依存しないことがわかった。

(3) 放電プラズマ焼結法によって得られた $\mathrm{Sr}$ 添加 $\mathrm{LaPO}_{4}$ 焼結 体は高温, 湿潤需囲気下において支配的なプロトン伝導を 示すことがわかった，またその導電率，伝導特性は，従来 の常圧焼結法による $\mathrm{Sr}$ 添加 $\mathrm{LaPO}_{4}$ 焼結体とほぼ同等で あった.

(4) 以上の結果から，本研究で採用した放電プラズマ焼結法 は，高温プロトン伝導性セラミックスの焼結に対し，電気 伝導特性を保持したまま焼結体密度を向上させることがで きる，非常に有効な焼結手法であることが示された．

\section{文 献}

1) H.Iwahara, T.Shimura and H.Matsumoto: "Protonic Conduction in Oxides at Elevated Temperatures and Their Possible Applications", Electrochemistry, 68(2000)154-161.

2) T.Norby: "Solid-state protonic conductors: principles, properties, progress and prospects", Solid State Ionics, 125(2000)1-11.

3) K.-D.Kreuer: "Proton Conductivity: Materials and Applications", Chem. Mater., 8(1996)610-641. 
4) T.Norby and N.Christiansen: "Proton conduction in $\mathrm{Ca}-$ and $\mathrm{Sr}-$ substituted $\mathrm{LaPO}_{4}{ }^{\prime}$, Solid State Ionics, 77(1995)240-243.

5) K.Amezawa, S.Kjelstrup, T.Norby and Y.Ito: "Protonic and Native Conduction in $\mathrm{Sr}$-Substituted $\mathrm{LaPO}_{4}$ Studied by Thermoelectric Power Measurements", J. Electrochem. Soc., 145(1999) 3313-3319.

6) K.Amezawa, H.Maekawa, Y.Tomii and N.Yamamoto: "Protonic conduction and defect structures in $\mathrm{Sr}$-doped $\mathrm{LaPO}_{4}$ ", Solid State Ionics, 145(2001)233-240.

7) K.Amezawa, Y.Tomii and N.Yamamoto: "High temperature protonic conduction in Ca-doped $\mathrm{YPO}_{4}$ ", Solid State Ionics, 162-3 (2003) 175-180.

8) K.Amezawa, Y.Tomii and N.Yamamoto: "High temperature protonic conduction in $\mathrm{Sr}_{2} \mathrm{P}_{2} \mathrm{O}_{7}-\mathrm{LaPO}_{4}$ system", Solid State Ionics, to be published.

9) 北村尚斗, 雨澤浩史, 富井洋一, 山本直一: " $\mathrm{Sr}$ 添加 $\mathrm{NdPO}_{4}$ における高温プロトン伝導"，粉体および粉末冶金，49 (2002)856-860.

10) N.Kitamura, K.Amezawa, Y.Tomii and N.Yamamoto: "Protonic conduction in rare earth orthophosphates with the monazite structure", Solid State Ionics, 162-3(2003)161-165.

11) N.Kitamura, K.Amezawa, Y.Tomii, N.Yamamoto and T.Hanada: "Protonic conduction in Sr-doped $\left(\mathrm{La}_{1-\mathrm{x}} \mathrm{Sm}_{\mathrm{x}}\right) \mathrm{PO}_{4}$ ", to be published.

12) K.Amezawa, Y.Tomii and N.Yamamoto: "High temperature protonic conduction in $\mathrm{La}_{7} \mathrm{P}_{3} \mathrm{O}_{18}$ ", Solid State Ionics, to be published.

13）雨澤浩史, 冨井洋一, 山本直一: "La-P-O 系焼結体の電気 伝導特性", 平成14年度粉体粉末冶金協会春季大会講演概 要集, (2003)53.

14) 北島幸典, 雨澤浩史, 北村尚斗, 冨井洋一,山本直一： "La-P-O 系焼結体の電気伝導特性(II)", 平成 14 年度粉体 粉末冶金協会秋季大会講演概要集 , (2003)139.

15) K.Amezawa, N.Takahashi, H.Kondo, N.Kitamura, Y.Tomii and N.Yamamoto: "High temperature protonic conduction in rare earth orthoborates with the Aragonite-type structure", Solid State Ionics, to be published.

16）高橋信之, 雨澤浩史, 北村尚斗，富井洋一，山本直一： " $\mathrm{La}_{2} \mathrm{O}_{3}-\mathrm{B}_{2} \mathrm{O}_{3}$ 系焼結体の電気伝導特性 ", 平成 14 年度粉体 粉末冶金協会秋季大会講演概要集, (2003)137. 